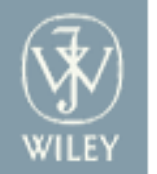

International Journal of Climatology

\title{
Observed trends in frost and hours of cold in Majorca
}

\begin{tabular}{|c|c|}
\hline Journal: & International Journal of Climatology \\
\hline Manuscript ID: & JOC-09-0168.R1 \\
\hline Wiley - Manuscript type: & Short Communication \\
\hline \multicolumn{2}{|l|}{$\begin{array}{r}\text { Date Submitted by the } \\
\text { Author: }\end{array}$} \\
\hline Complete List of Authors: & $\begin{array}{l}\text { Cuxart, Joan; University of the Balearic Islands, Physics } \\
\text { Guijarro, Jose Antonio; Agencia Estatal de Meteorologia, D.T en } \\
\text { Illes Balears }\end{array}$ \\
\hline Keywords: & $\begin{array}{l}\text { series of minimum temperature, Majorca, frost, hours-of-cold, cloud } \\
\text { cover, warmer winters, agricultural damage }\end{array}$ \\
\hline
\end{tabular}

\section{S ScholarONE" \\ Manuscript Central}


Observed trends in frost and hours of cold in Majorca

Short title: Cold in Majorca

Authors: J. Cuxart (1*) and J.A. Guijarro (2)

(1) Universitat de les Illes Balears (UIB), Grup de Meteorologia

(2) Agencia Estatal de Meteorologia (AEMET), D.T. en Illes Balears

(*) Corresponding author address: Facultat de Ciències, Carretera de

Valldemossa km 7.5; 07122 Palma; Illes Balears.joan.cuxart@uib.cat; Ph: +34 971 171375; Fax: +34 971173426 


\begin{abstract}
:
The observed trends on some cold indexes in the island of Majorca are analyzed using the available series of the daily minimum temperatures of the Majorca Airport (19722008), supplemented with the inspection of eight more climatological stations of the island covering at least thirty simultaneous years. The analysis yields a statistically significant trend to a rise of about $0.6^{\circ} \mathrm{C}$ per decade for the ensemble of the stations. There is also a clear shortening of the season with days with $\mathrm{T}$ below $0^{\circ} \mathrm{C}$ or $7^{\circ} \mathrm{C}$, but the yearly minima or the dates of the first and last occurence of these values do not show so well defined tendencies. A rise in nightime cloud cover could be related to such behaviour.
\end{abstract}

Keywords: series of minimum temperature, Majorca. warmer winters, frost, hours of cold, cloud cover

Acknowledgements: The Spanish Agency of Meteorology (AEMET) has provided the time series. The Spanish Ministry of Science funds partially this work through grant CGL2006-12474-C01. M. A. Jiménez (UIB) is acknowledged for her help with figure 1. 


\section{Introduction}

In the frame of the global warning, a number of issues are relevant locally. In this research note, the August 1972- May 2008 series of the Palma Airport -and eight more series of Majorca of 30 or more years- (Balearic Islands, Western Mediterranean) of minimum temperatures are analyzed to inspect if there is a significant trend to warmer winters and reduction of the risk of frost, mainly with agricultural intention.

A study with a similar purpose for the United States was made by Easterling (2002) with a large number of stations, that showed a significant trend to the reduction of the number of frost days at the national scale, at a rate of 0.8 days per decade for the period 1948-1999, with large regional differences. Other studies include those of Menzel et al. (2003), showing many stations in Germany, Austria and Estonia with significant changes in these parameters, for instance 4.9 days per decade more of the frost-free period between 1951 and 2000, or Bartolini et al. (2008) that show increases of more than $0.2^{\circ} \mathrm{C}$ per decade in the minimum temperatures for Tuscany during $1955-2004$. Not all these indices are directly comparable, but they all point in the same direction. The Fourth Assesment Report of the IPCC (Trenberth et al., 2007) provides estimations for land over the northern hemisphere of increases of about $0.3 \mathrm{C}$ per decade for the minimum temperatures (based on Vose et al, 2005) and 0.2 per ${ }^{\circ} \mathrm{C}$ decade for the mean temperature over ocean (based on Rayner et al, 2006) for the period 1979-2005, similar to the one studied here. The fact that Majorca is a piece of land in the middle of the Mediterranean sea makes interesting to look at its specific behaviour. 
Majorca is the largest island of the Balearic archipelago, located in the Western Mediterranean about $200 \mathrm{~km}$ offshore of the coast of the Iberian Peninsula (Fig. 1a). The island has a characteristic size of $100 \mathrm{~km}$ with a large mountain range (Serra de Tramuntana) occupying all its northwestern side (peaking at $1436 \mathrm{~m}$ above sea level ASL-). The rest of the island consists summarily in three basins, two at the southern side (Palma at west and Campos at the east) and one at the northern side (Alcúdia), with an elevated area in the center of the island (Randa, 556 ASL) and a lower mountain range at the east (Serra de Llevant, peaking at $520 \mathrm{~m} \mathrm{ASL)}$-see Figure 1b. A study by Cuxart et al. (2007) found that, under clear skies and with weak pressure gradients, when strong local surface cooling may occur, the flow is organized by basins, each having sea-breezes in the daytime and convergence of drainage flows in nighttime, with formation of cold pools in the valleys and cold outflow to the sea. These conclusions were reproduced by Jimenez et al. (2008), in a work that verified the structures in the island using the thermal structures produced by infrared satellite imagery. The fact that the island is relatively small and surrounded by an almost closed sea may indicate that a warming there is regionally relevant.

The main agricultural cultures in the archipelago are ornamental plants, fruits (including vines), potatoes and green vegetables. The productivity of the latter is mainly affected by frosts whereas fruit trees have also specific requirements of hours-of-cold (customarily defined as hours with temperature below $7^{\circ} \mathrm{C}$ ). Any significant trend may induce significant changes in the agriculture of the islands, thus in the economy and the landscape, since $37 \%$ of the surface is cultivated land. To illustrate the impact of frost episodes, all cultures of the island are listed in the insurance coverages by the spanish 


\section{The series}

In Figure 1b, the locations of the nine analyzed stations are displayed. The Airport Meteorological Station (WMO principal station) is located in the eastern part of the Palma basin, at a distance of $9 \mathrm{~km}$ from downtown Palma and at $5 \mathrm{~km}$ of its continuous urbanized area. The data are taken at the northern end of the runaway, $5 \mathrm{~km}$ inland, in a local depression of the terrain where cold air can cumulate in clear and calm nights (Cuxart et al., 2007). The series starts in August 1972, complying with all the requirements of a primary WMO station; it is managed and quality-controlled by the Spanish Meteorological Agency (AEMET). The series of minimum temperatures from 1 August 1972 to 31 May 2008 has been extracted from the data base.

Eight other stations from the climatological database of AEMET have been used provided that they had at least 30 years falling in the period 1972-2008. In the Palma 
basin, besides the airport, there is Portopí, in the harbour of the city of Palma (19782008, 3m ASL) and Sa Cabaneta, close to elevated plateau in the center of the island (1976-2008, 152 m ASL). In the Campos basin, we could consider Llucmajor (19742008, 140 m ASL), also in an elevated part between the Palma and Campos basins, and Ses Salines (1972-2008, 3m ASL), very near to the coast but in the center of the valley. In the Alcúdia basin, the station of Muro is available (1974-2008, $50 \mathrm{~m}$ ASL) in the flat central part of the basin, and Manacor (1974-2008, $125 \mathrm{~m}$ ) which is more inland and to the East. Finally, two stations are in the main Tramuntana Range, Lluc (1972-2008, 490 m ASL) and Orient (1975-2008, 455 m ASL), both located at the bottom of elevated closed mountain valleys.

The series consist of the daily minimum temperatures, with very few missing data. The analysis of trends for the main series has been made for complete years to avoid the effect of starting an analysis in winter and finishing it in summer, which would provide spurious warming. All the selected series start and finish in summer for this purpose. To study their relative homogeneity, they were first standardized, and reference series for each station were computed as an average of their neighbours, weighted by an inverse distance function. Then, the differences between the original and computed series were scrutinized in search of possible shifts in the average, by means of applying two sample Student t-tests to two adjacent running windows of four years (48 monthly values per sample) along all the series (in this way, four years is the maximum temporal resolution to detect shifts either consecutive of at the beginning or the end of the series). 
This lead to the detection of clear shifts in the mean in two of the series, at the following dates: 1) March 1983 in Muro, due to a documented bad siting of the thermometer (on a terrace); and 2) May 1984 in Manacor, for which no metadata were found to explain this inhomogeneity. Therefore, data previous to the shifts were deleted from the Muro and Manacor series in order to avoid misleading results. The rest of the compared series showed minor differences, indistinguishable from natural variability, and therefore no further corrective measures were attempted. The statistical analyses have been done with the R statistical package (R Development Core Team, 2008), package "Climatol" (Guijarro, 2006), version 2.0.

\section{Trends of minimum temperatures and cold indexes}

The trends for daily minimum series have been computed for the nine locations and the values are given in Table 1, keeping only the restricted ranges for the two stations with confirmed inhomogeneities. In that table the stations are ordered from warmer to colder in respect to the average minimum temperature. The trends have been computed by the least-squares methods and the confidence levels have been assessed with the nonparametric Mann-Kendall test (1975), to overcome the lack of normality of the series of the daily minimum temperatures. All the stations have positive slopes statistically significant at least with a $95 \%$ confidence. An averaged central value for the ensemble of the stations is $0.6^{\circ} \mathrm{C}$ per decade, the double of the estimation of the IPCC (Trenberth et al) for the northern hemisphere over land. This indicates that there is a warming of 
the nocturnal temperatures in the island at all kinds of landscape and height, since stations are near the coast, in the valleys, in plateaux or mountain ranges. In the case of the Airport, the complete series has a correlation coefficient of 0.11 , meaning that most of the variability is not explained by the linear regression. This is not strange, since minima for this station can vary from -6 to $27^{\circ} \mathrm{C}$ and most of the variance is explained by the annual cycle.

A number of indices have been obtained from each series, namely i) the yearly minimum temperature value; ii) the number of days below $0^{\circ} \mathrm{C}$, iii) the first day with $\mathrm{T}$ below $0^{\circ} \mathrm{C}$, iv) the last day below $0^{\circ} \mathrm{C}, \mathrm{v}$ ) the number of days below $7^{\circ} \mathrm{C}$, vi) the first day with $\mathrm{T}$ below $7^{\circ} \mathrm{C}$, and vii) the last day below $7^{\circ} \mathrm{C}$. The resulting anual series for the Airport are plotted in Figure 2. The absolute annual minimum temperature is shown to have a smaller trend than the annual anomaly of the same quantity. Although at a first glance the linear adjustments seem to indicate a behaviour consistent with a general warming, some of these results are not statistically significant and deserve further analysis.

Also in Table 1 the average values and the trends for the yearly minimum temperature are given. Average values below zero are found in the mountain range and in the bottom of the valleys. However only half of the stations show a significant increase, making less clear the trend to higher absolute yearly minimum temperatures in the Island.

Table 2 displays statistics related to frost days. Averages above 1 day per year are found only in four stations in the mountain and in the valleys and at all these stations there is a 
significant trend to diminish the number of days, with an ensemble central value of -4.7 days per decade, a trend that would indicate that frost would disappear from the valleys in about 4 decades. However the bottom end of the $95 \%$ interval is very low for three of the four stations $(-0.2,-0.9$ and -1.4 days/decade) and it suggests to be prudent in any conclusion regarding this issue. There is not a well defined trend for the occurence of the first frost for these stations, although one can see that the last spring frost seems to come earlier (about 12 days per decade).

Similar conclusions are reached with the same indices using days with temperatures below $7^{\circ} \mathrm{C}$ (Table 3). Eight of the nine stations show a decrease in the number of days, since Llucmajor does not yield any significant trend. It cannot be said that the first day with temperature below $7^{\circ} \mathrm{C}$ has a well defined tendency for the ensemble of stations, but six of nine stations show statistically significant trend to earlier end of cold days. Since some hundreds of hours below $7^{\circ} \mathrm{C}$ are needed by fruit trees in their winter rest, and the average computed decrease is about 12 days below $7^{\circ} \mathrm{C}$ per decade, some of the current plantations in the Balearic Islands may cease to be possible, at least with the present-day plant varieties.

\section{Trends on cloudiness and relative insolation}

The fact that minimum temperatures seem to be increasing and the number of days of frost $\left(\mathrm{T}<0^{\circ} \mathrm{C}\right)$ and of cold $\left(\mathrm{T}<7^{\circ} \mathrm{C}\right)$ decreasing in a statistical significant way, while less significance is reached for the absolute yearly minimum temperature or the dates of the first and last dates for the ensemble of the stations, may indicate some link to 
changes in cloud cover. If the amount of clouds during night (or the number of cloudy nights) increased, it might explain the rising of the minimum temperatures, whereas the clear nights would cool as much as usual, thus allowing for similar yearly minimum temperatures. The dates of first and last frost not significantly changed would then be related to the fact that, whenever a clear and calm night occurs, similar intense cooling as before can occur.

In table 4, the trends are computed for the humanly estimated cloud cover at 7, 13 and 18 local solar time plus the relative insolation extracted from the burned heliograph bands. These measurements have a larger amount of uncertainty than temperatures, due to the human factor in estimation of cloud cover and portion of band burned.

There is a statistically significant increase of clouds (low and total) at 7 local solar time, a moment normally close to the time of the minimum temperature and a decrease of low clouds at 13 and 18 . This is combined with a small increase for the relative insolation. This increase of late-night clouds would lead to higher minima for cloudy nights and would be compatible with less significant trends for values usually found in clear and calm nights, such as yearly minimum temperature. The increase of minimum temperatures could thus be related, at least partially, to higher nocturnal thermal stability, with more inversions -and therefore fog and low clouds-, while this stability would also be compatible with a lower daily cloudiness and the corresponding increase in relative sunshine hours. 
The connection between these variables has been investigated by adjusting a multiple regression model to the minimum daily temperatures, using cloudiness and relative insolation as the independent variables. But first, all the variables have been detrended, and their seasonal components removed by substracting the annual cycle and the first two harmonics of a Fourier analysis adjusted to the original data. In this way, the variance of the minimum temperatures was reduced by a $75 \%$ (standard deviation of $6.3^{\circ} \mathrm{C}$ in the original data and $3.1^{\circ} \mathrm{C}$ in the deseasonalized one).

The residual series were then used to adjust the multiple regression model and, although the explained variance of the minimum temperatures amounts only to $15 \%$, only the low cloudiness at 18 UTC was not significant at the $95 \%$ confidence level. The signs of the significant contributions (Table 4) of the independent variables are in accordance with the aforementioned interpretation of their trends.

\section{Conclusions}

For the ensemble of the studied stations located in the island of Majorca in the Western Mediterranean, the analysis of the minimum temperatures for the last three decades seems to imply that there is a statistically significant trend to increase, at about $0.6^{\circ} \mathrm{C}$ per decade at a $95 \%$ confidence level, more than the hemispheric estimations provided by IPCC of about $0.3^{\circ} \mathrm{C}$ per decade . This goes together with a diminition of the number of days of frost $\left(\mathrm{T}<0^{\circ} \mathrm{C}\right)$ or of cold $\left(\mathrm{T}<7^{\circ} \mathrm{C}\right)$. Instead, the absolute yearly minimum temperature or the dates of the first and last frost days do not show a significant trend in 
the ensemble. A possible link to cloud cover is considered, since this quantity has significantly increased at 7 AM local solar time, that may partially explain the rise of the minimum temperatures. In summary, warmer winters seem to be on place that may induce relevant changes in the agricultural landscape of the region, but being aware that frost events can take place as it has been usual in the last decades. 


\section{References}

Bartolini G, Morabito M, Crisci A, Grifoni D, Torrigiani T, Petralli, M, Marracchi G, Orlandini S. 2008. Recent trends in Tuscany (Italy) summer temperature and indices of extremes. International Journal of Climatology 28: 1751-1760. DOI: 10.1002/joc.1673 Cuxart J, Jimenez MA, Martinez D. 2007. Nocturnal Meso-Beta Basin and Katabatic Flows on a Midlatitude Island. Monthly Weather Review 135: 918-932. DOI: 10.1175/MWR3329.1

Easterling DR. 2002. Recent changes in frost days and the frost-free season in the United States. Bulletin of the American Meteorological Society 83: 1327-1332 Guijarro, JA. 2006. Homogenization of a dense thermo-pluviometric monthly database in the Balearic Islands using the free contributed R package CLIMATOL. WMO Fifth Seminar for Homogenization and Quality Control in Climatological Databases. Budapest, Hungary, 2006; WCDMP-No. 68, WMO-TD No. 1434, 2008. Jiménez MA, Mira A, Cuxart J, Luque A, Alonso S, Guijarro, JA. 2008. Verification of a clear-sky mesoscale simulation using satellite-derived surface temperatures. Monthly Weather Review 136: 5148-5161. DOI: 10.1175/2008MWR2461.

Kalma JD, Laughlin GP, Caprio JM, Hamer PJC. 1992. The bioclimatology of frost. Its occurence, impact and protection. Advances in Bioclimatology 2, pp 144, SpringerVerlag

Kendall MG. 1975. Rank Correlation Methods, Charles Griffin, London Menzel A, Jakobi G, Ahas R, Scheifinger H, Estrella N. 2003. Variations of the climatological growing season (1951-2000) in Germany compred to other countries. International Journal of Climatolology 23: 793-812. DOI: 10.1002/joc.915 R Development Core Team (2008). R: A language and environment for statistical 
computing. R Foundation for Statistical Computing, Vienna, Austria. ISBN 3-90005107-0, URL http://www.R-project.org.

Rayner, N.A., et al., 2006: Improved analyses of changes and uncertainties in sea surface temperature measured in situ since the mid-nineteenth century: the HadSST2 dataset. J. Clim., 19, 446-469

Riera, A and Ripoll, AM, 2009: Informe econòmic i social de les Illes Balears, 2008, Centre de Recerca Econòmica, UIB-Sa Nostra, Palma, Spain, ISBN 978-84-92863-00-6 Snyder R, de Melo Abreu J. 2005. Frost Protection: fundamentals, practice and economics, vol 1. Service Series 10, FAO, Roma Trenberth KE, Jones PD, Ambenje P, Bojariu R, Easterling D, Klein Tank A, Parker D, Rahimzadeh F, Renwick JA, Rusticucci M, Soden B, Zhai P. 2007. Observations: Surface and Atmospheric Climate Change. In: Climate Change 2007: The Physical Science Basis. Contribution of Working Group I to the Fourth Assessment Report of the Intergovernmental Panel on Climate Change [Solomon S, Qin D, Manning M, Chen Z, Marquis M, Averyt KB, Tignor M, Miller HL(eds.)]. Cambridge University Press, Cambridge, United Kingdom and New York, NY, USA.

Vose, R.S., D.R. Easterling, and B. Gleason, 2005: Maximum and minimum temperature trends for the globe: An update through 2004. Geophys. Res. Lett., 32, L23822, doi:10.1029/2004GL024379. 


\section{Tables}

Table 1: Statistics of the daily and annual series of minimum temperatures for 8 selected Majorca stations. Average of the daily series is $0.60 \mathrm{C} / \mathrm{decade}$. In bold regressions with confidence level higher than $95 \%$.

\begin{tabular}{|c|c|c|c|c|}
\hline & $\begin{array}{l}\text { Average } \\
\text { Daily T } \\
\text { min }\end{array}$ & $\begin{array}{l}\text { Slope and 95\% } \\
\text { conf interval } \\
\text { (C/decade) }\end{array}$ & $\begin{array}{l}\text { Average } \\
\text { annual T } \\
\text { min }\end{array}$ & $\begin{array}{l}\text { Slope and } 95 \% \\
\text { conf. interval (C/ } \\
\text { decade) }\end{array}$ \\
\hline $\begin{array}{l}\text { Palma Harbour (78-08) } \\
\text {-Coast- }\end{array}$ & $14.5 \mathrm{C}$ & $\begin{array}{l}0.59 \\
(0.48,0.71)\end{array}$ & $3.0 \mathrm{C}$ & $\begin{array}{l}0.32 \\
(-0.30,0.94)\end{array}$ \\
\hline $\begin{array}{l}\text { Sa Cabaneta (76-08) } \\
\text {-Plateau- }\end{array}$ & $13.1 \mathrm{C}$ & $\begin{array}{l}0.62 \\
(0.51,0.73)\end{array}$ & $1.2 \mathrm{C}$ & $\begin{array}{l}0.45 \\
(-0.18,1.08)\end{array}$ \\
\hline $\begin{array}{l}\text { Muro *(83-08) } \\
- \text { Valley- }\end{array}$ & $12.8 \mathrm{C}$ & $\begin{array}{l}0.69 \\
(0.52,0.85)\end{array}$ & $0.4 \mathrm{C}$ & $\begin{array}{l}1.28 \\
(0.62,1.64)\end{array}$ \\
\hline $\begin{array}{l}\text { Llucmajor (74-08) } \\
\text {-Plateau- }\end{array}$ & $12.6 \mathrm{C}$ & $\begin{array}{l}0.34 \\
(0.23,0.45)\end{array}$ & $1.2 \mathrm{C}$ & $\begin{array}{l}0.03 \\
(-0.45,0.52)\end{array}$ \\
\hline $\begin{array}{l}\text { Manacor* (84-08) } \\
\text {-Valley- }\end{array}$ & $11.8 \mathrm{C}$ & $\begin{array}{l}0.70 \\
(0.53,0.84)\end{array}$ & $-1.0 \mathrm{C}$ & $\begin{array}{l}1.43 \\
(-0.55,2.31)\end{array}$ \\
\hline $\begin{array}{l}\text { Ses Salines (72-08) } \\
\text { - Valley- }\end{array}$ & $10.5 \mathrm{C}$ & $\begin{array}{l}0.31 \\
(0.18,0.44)\end{array}$ & $-2.8 \mathrm{C}$ & $\begin{array}{l}1.38 \\
(0.61,2.16)\end{array}$ \\
\hline $\begin{array}{l}\text { Airport (72-08) } \\
\text {-Valley-- }\end{array}$ & $10.3 \mathrm{C}$ & $\begin{array}{l}0.64 \\
(0.54,0.75)\end{array}$ & $-2.9 \mathrm{C}$ & $\begin{array}{l}0.30 \\
(-0.05,0.65)\end{array}$ \\
\hline $\begin{array}{l}\text { Orient (75-08) } \\
\text {-Mountain- }\end{array}$ & $8.4 \mathrm{C}$ & $\begin{array}{l}0.99 \\
(0.89,1.09)\end{array}$ & $-2.9 \mathrm{C}$ & $\begin{array}{l}0.88 \\
(0.37,1.38)\end{array}$ \\
\hline
\end{tabular}




\begin{tabular}{|l|l|l|l|l|}
\hline Lluc (72-08) & $8.0 \mathrm{C}$ & $\mathbf{0 . 5 5}$ & $-4.6 \mathrm{C}$ & $\mathbf{0 . 6 2}$ \\
-Mountain- & & $\mathbf{( 0 . 4 5 , 0 . 6 5 )}$ & & $\mathbf{( 0 . 1 3 , \mathbf { 1 . 1 1 } )}$ \\
\hline
\end{tabular}

Manacor (74-84) 
Table 2: days with $\mathrm{T}<0$ (definition of day with frost). Day 1 is 1 st January.

\begin{tabular}{|l|l|l|l|l|l|l|}
\hline & $\begin{array}{l}\text { Average } \\
\text { Number }\end{array}$ & $\begin{array}{l}\text { Slope 95\% } \\
\text { of days }\end{array}$ & Average & Slope 95\% & Average & Slope 95\% \\
& & First day & (per decade) & Last day & (per decade) \\
\hline Palma Harbour & 0 & N.A. & N.A. & N.A. & N.A. & N.A. \\
\hline Sa Cabaneta & 0.4 & N.A. & N.A. & N.A. & N.A. & N.A. \\
\hline Muro & 0.8 & N.A. & N.A. & N.A. & N.A. & N.A. \\
\hline Llucmajor & 0.1 & N.A. & N.A. & N.A. & N.A. & N.A. \\
\hline Manacor & 0.8 & N.A. & N.A. & N.A. & N.A. & N.A. \\
\hline Ses Salines & 13 & $\mathbf{( - 8 . 8 , - 4 . 3 )}$ & $-9(23 D)$ & $\mathbf{( 2 . 8 , 1 7 . 2 )}$ & $62(3 \mathrm{M})$ & $\mathbf{( - 2 8 . 9 , - 1 3 . 1 )}$ \\
\hline Airport & 13 & $\mathbf{( - 5 . 4 , - 0 . 9 )}$ & $-9(23 D)$ & $(-1.5,13.7)$ & $70(11 M)$ & $\mathbf{( - 1 7 . 4 , ~ - 3 . 8 ) ~}$ \\
\hline Orient & 12 & $\mathbf{( - 7 . 7 , - 1 . 4 )}$ & $-2(30 D)$ & $(-6.1,20.5)$ & $71(12 M)$ & $\mathbf{( - 2 1 . 6 , - 5 . 1 )}$ \\
\hline Lluc & 36 & $\mathbf{( - 9 . 7 , - 0 . 2 )}$ & $-29(3 D)$ & $(-1.7,11.6)$ & $85(26 M)$ & $(-12.0,5.6)$ \\
\hline
\end{tabular}


Table 3: Number of days with $T<7$ (definition of day with hours-of-cold). Day 1 is 1 st January.

\begin{tabular}{|l|l|l|l|l|l|l|}
\hline & $\begin{array}{l}\text { Average } \\
\text { number }\end{array}$ & Slope 95\% & Average & Slope 95\% & Average & Slope 95\% \\
& of days & & first day & (per decade) & last day & (per decade) \\
\hline Palma Harbour & 28 & $\mathbf{( - 1 3 . 5 , - 2 . 0 )}$ & $-20(12 \mathrm{D})$ & $(-9.8,9.9)$ & $78(19 \mathrm{M})$ & $(-16.9,2.9)$ \\
\hline Sa Cabaneta & 49 & $\mathbf{( - 1 3 . 4 , - 0 . 5 )}$ & $-33(29 \mathrm{~N})$ & $(-1.0,11.0)$ & $97(7 \mathrm{~A})$ & $\mathbf{( - 1 5 . 6 , - 2 . 6}$ \\
\hline Muro & 72 & $\mathbf{( - 2 1 . 4 , - 1 . 7 )}$ & $-43(19 \mathrm{~N})$ & $(-2.8,12.6)$ & $104(14 \mathrm{~A})$ & $\mathbf{( - 1 8 . 0 , - 3 . 8 )}$ \\
\hline Llucmajor & 62 & $\mathbf{( - 5 . 6 , 7 . 2 )}$ & $-40(22 \mathrm{~N})$ & $\mathbf{( - 5 . 2 , 5 . 6 )}$ & $100(10 \mathrm{~A})$ & $\mathbf{( - 7 . 9 , 0 . 4 )}$ \\
\hline Manacor & 91 & $\mathbf{( - 2 3 . 8 , - 4 . 9 )}$ & $-47(15 \mathrm{~N})$ & $\mathbf{( - 9 . 4 , 1 4 . 3 )}$ & $115(25 \mathrm{~A})$ & $\mathbf{( - 1 3 . 0 , 2 . 3 )}$ \\
\hline Ses Salines & 110 & $\mathbf{( - 2 9 . 7 , - 7 . 5 )}$ & $-55(7 \mathrm{~N})$ & $\mathbf{( 5 . 0 , 1 7 . 2 )}$ & $117(27 \mathrm{~A})$ & $\mathbf{( - 3 5 . 4 , - 9 . 7 )}$ \\
\hline Airport & 127 & $\mathbf{( - 1 6 . 8 , - 7 . 3 )}$ & $-63(29 \mathrm{O})$ & $\mathbf{( 2 . 8 , 1 0 . 5 )}$ & $133(12 \mathrm{My})$ & $\mathbf{( - 1 3 . 5 , - 6 . 1 )}$ \\
\hline Orient & 145 & $\mathbf{( - 3 3 . 7 , - 1 6 . 6 )}$ & $-77(15 \mathrm{O})$ & $\mathbf{( 1 . 5 , 1 1 . 1 )}$ & $141(12 \mathrm{My})$ & $\mathbf{( - 1 4 . 9 , - 5 . 4 )}$ \\
\hline Lluc & 159 & $\mathbf{( - 2 5 . 2 , - 3 . 8 )}$ & $-80(12 \mathrm{O})$ & $\mathbf{( - 1 0 . 9 , 1 . 6 )}$ & $139(18 \mathrm{My})$ & $\mathbf{( - 1 3 . 6 , 6 . 9 )}$ \\
\hline
\end{tabular}


Table 4: Averages (octas and percent) and trends (percent per decade) for cloudiness and relative insolation at Palma airport (1972-2008). Trends statistically significant at the $95 \%$ level are in bold. The third row displays the sign of the significant coefficients of a multiple regression between daily minimum temperature and these variables ("b" is the regression coefficient in Var=a+bTmin).

\begin{tabular}{|c|c|c|c|c|c|c|c|}
\hline & $\begin{array}{l}\text { Low } \\
\text { clouds } 7\end{array}$ & $\begin{array}{l}\text { Total } \\
\text { clouds } 7\end{array}$ & $\begin{array}{l}\text { Low } \\
\text { clouds } 13\end{array}$ & $\begin{array}{l}\text { Total } \\
\text { clouds } 13\end{array}$ & $\begin{array}{l}\text { Low } \\
\text { clouds } 18\end{array}$ & $\begin{array}{l}\text { Total } \\
\text { clouds } 18\end{array}$ & $\begin{array}{l}\text { Relative } \\
\text { insolation }\end{array}$ \\
\hline Average & 2.0 & 3.7 & 2.3 & 3.9 & 1.8 & 3.6 & $60.8 \%$ \\
\hline Trend & $1.9 \%$ & $2.2 \%$ & $-2.4 \%$ & $-0.3 \%$ & $-1.7 \%$ & $0.3 \%$ & $1.3 \%$ \\
\hline $\begin{array}{l}\text { Sign of } \\
\text { significant } \\
\text { b }\end{array}$ & + & + & & + & 0 & + & - \\
\hline
\end{tabular}


Figure 1: (a) Majorca in the Western Mediterranean; (b) Topographic map of the Majorca island with the locations of the stations used.

Figure 2. Top: annual anomaly of the minimum temperature and absolute annual minimum temperature, second: number of days below $0 \mathrm{C}$; third: number of days below $7 \mathrm{C}$; fourth: first day below $0^{\circ} \mathrm{C}$ and below $7 \mathrm{C}$; bottom: last day below 0 and below $7^{\circ} \mathrm{C}$. Each figure has regression lines for the complete series. 


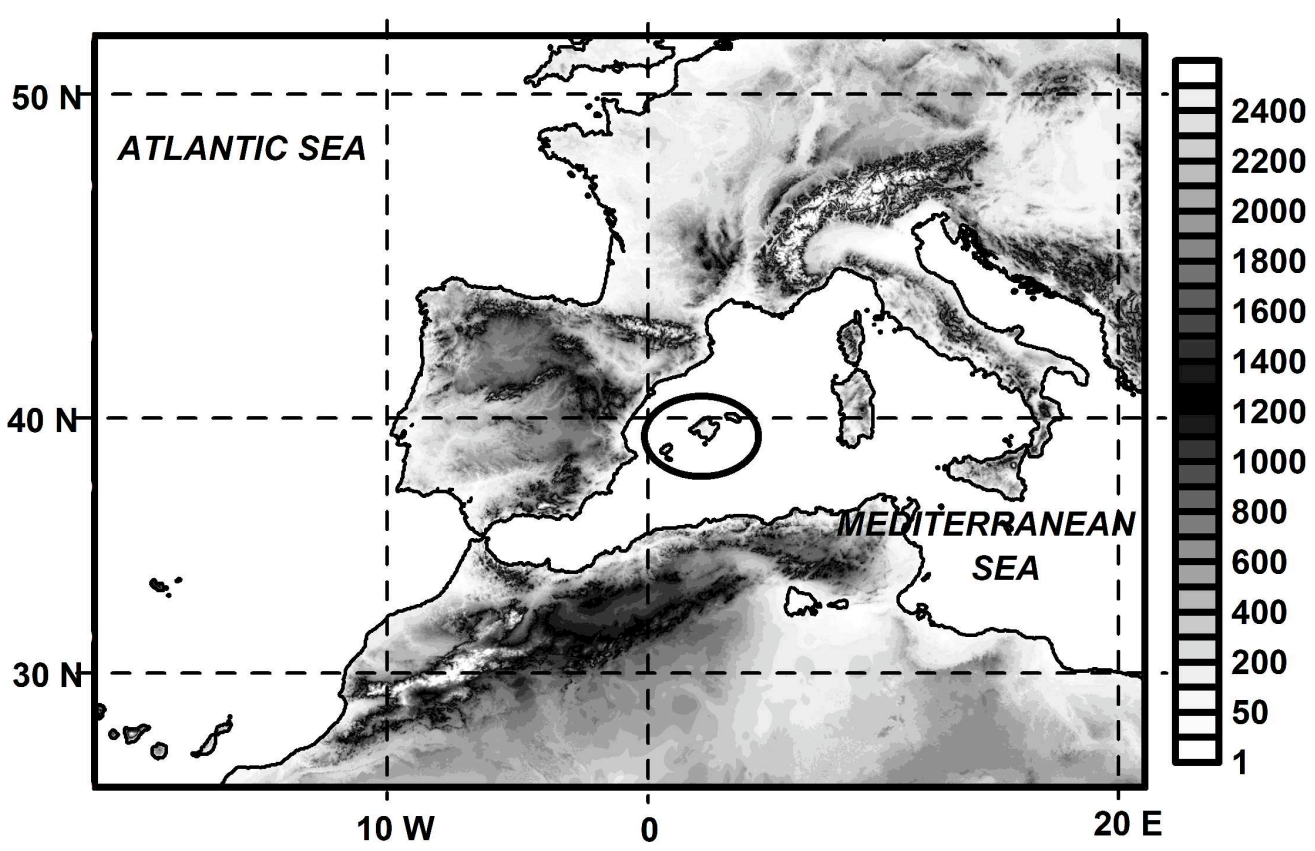

Figure 1: (a) Majorca in the Western Mediterranean $1561 \times 995 \mathrm{~mm}(72 \times 72 \mathrm{DPI})$ 


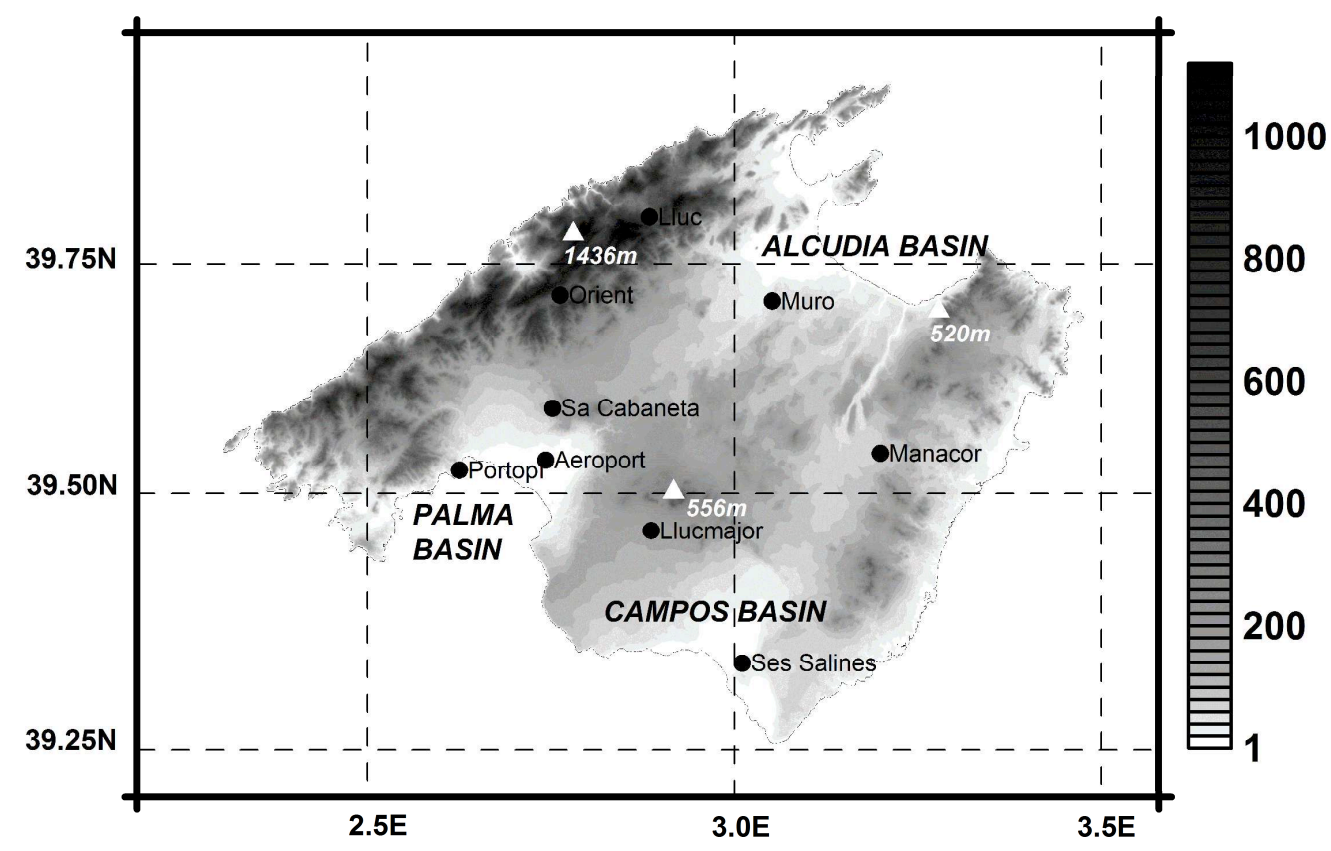

Figure 1: (b) Topographic map of the Majorca island with the locations of the stations used. $1594 \times 1034 \mathrm{~mm}(72 \times 72 \mathrm{DPI})$ 

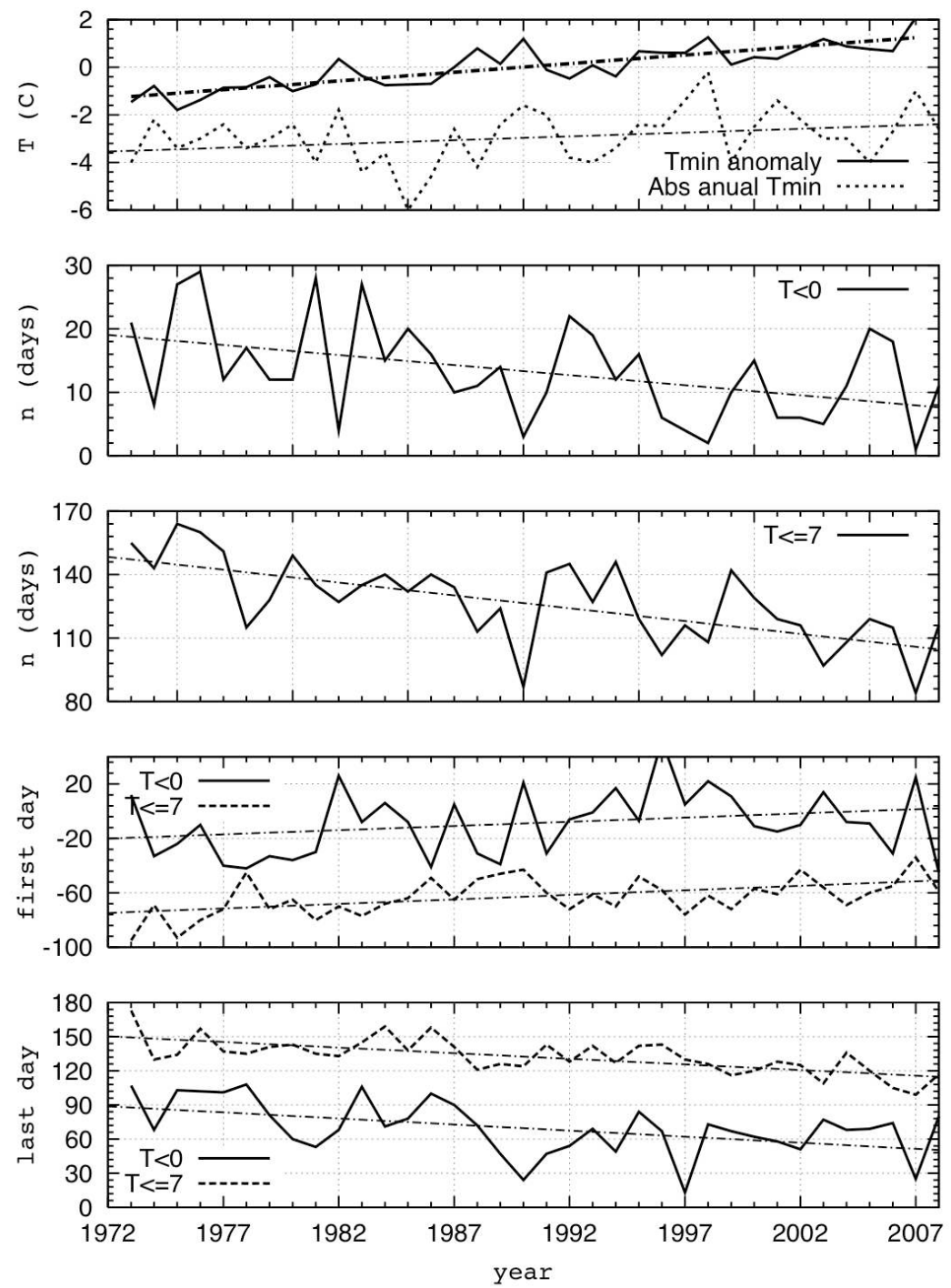

$207 \times 268 \mathrm{~mm}(150 \times 150 \mathrm{DPI})$ 